Portland State University

PDXScholar

$1-1-2003$

\title{
The Strategy of Sustainability: A Systems Perspective on Environmental Initiatives
}

\author{
Scott Marshall \\ Portland State University, rsm@pdx.edu \\ Darrell Brown \\ Portland State University
}

Follow this and additional works at: https://pdxscholar.library.pdx.edu/busadmin_fac

Part of the Business Commons

Let us know how access to this document benefits you.

\section{Citation Details}

Marshall, R., \& Brown, D. "The Strategy of Sustainability: A Systems Perspective of Environmental Initiatives," in California Management Review, vol. 46, no 1, 2003.

This Article is brought to you for free and open access. It has been accepted for inclusion in Business Faculty Publications and Presentations by an authorized administrator of PDXScholar. Please contact us if we can make this document more accessible: pdxscholar@pdx.edu. 


\title{
The Strategy of
} Sustainability:

\section{A SYSTEMS PERSPECTIVE ON ENVIRONMENTAL INITIATIVES}

\author{
R. Scott Marshall \\ Darrell Brown
}

"Sustainable development is not an event, it's a process. We must switch from linear thinking to systems thinking."

—Anita Burke, Sustainable Development Advisor, Shell International B.V. ${ }^{1}$

$\mathrm{T}$

he concept of sustainability is often defined as "the ability of current generations to meet their needs without compromising the ability of future generations to meet theirs." ${ }^{2}$ This definition, however, provides no guides for action. A more practical working definition of sustainability principles has focused on the "triple bottom line," ${ }^{3}$ where companies simultaneously consider their financial, social, and environmental performance. However, translating the triple-bottom-line conception of sustainability into actionable steps and investments has proven to be difficult for most companies. Leading firms in the area of sustainability are taking various approaches to implementing sustainable business practices, with mixed success. ${ }^{4}$ Since each company possesses different organizational resources and relationships they will likely pursue sustainability by different means and in different organizational structures. ${ }^{5}$ A key question confronting firms that have adopted or are considering adopting sustainable strategies, therefore, is: How should sustainability actually be pursued? ${ }^{6}$

A systems perspective can guide the pursuit of sustainability, and the field of systems dynamics provides valuable tools for companies endeavoring to be more sustainable. Several environmental initiatives of Norm Thompson Outfitters (NTO), ${ }^{7}$ a catalog retail company that has been incorporating the principles of environmental sustainability into its strategy and practices for over a decade, demonstrates the usefulness of a systems dynamics approach. NTO management 
clearly recognizes that achieving environmental sustainability is a long-term proposition.

\section{An Overview of Systems Dynamics}

Jay Forrester describes a system as "a grouping of parts that operate together for a common purpose." ${ }^{8}$ Systems dynamics analyzes how feedback processes in a system generate or alter patterns of behavior. The system may include decision-making procedures, work and process flows, attitudes and perceptions, and product quality. ${ }^{9}$

Systems dynamics diagrams employ graphic representations of feedback loops to illustrate the complexity of system processes. A feedback loop is a closed path connecting a sequence of decisions that control action, the states or conditions of the system, and information about the conditions of the system. ${ }^{10}$ Feedback loops connect stock variables, which are the accumulations of actions within a system, and flow variables, which are the rate of change in the stock variables. For example, Stock A (hours of input labor) would relate to Flow A (production rate per day). Flow A would relate to the level of Stock B (inventory level). A decrease in the hours of input labor would reduce production rate per day causing a reduction in inventory level. Systems diagrams show these and other related components (such as rate of sales) so that observers can see the relationships of the organization and how those relationships affect the organization's operations.

Developing a systems dynamics diagram includes several steps. The analyst starts with a problem definition, identifies key variables and their behaviors over time, and shows the causal links between them. The analyst diagrams these components, creating a dynamic model of the system that can be used to antici-

R. Scott Marshall is an Assistant Professor of Management at Portland State University. <scottm@sba.pdx.edu>

Darrell Brown is an Associate Professor of Accounting at Portland State University. $<$ darrellb@sba.pdx.edu> pate how changes in system components affect other parts of the system. ${ }^{11}$ Table 1 describes the fundamental components of systems diagrams, which include stocks and flows, feedback loops, gaps, delays, and leverage points. These tools are useful for understanding, developing, and implementing sustainability initiatives from an

organizational perspective. (For more comprehensive coverage of systems dynamics and thinking, see Forrester's Principles of Systems and Peter Senge's The Fifth Discipline). ${ }^{12}$

Regardless of the state of a firm's sustainability efforts, systems dynamics modeling can help a firm assess its recent behavior as well as plan for future organizational action. That is, systems dynamics may be used as both a learning and a planning tool. Table 2 outlines the key steps that we took to analyze NTO's initiatives. Appendix 1 gives a description of our research methodology. 
TABLE I. Components of Systems Diagrams

\begin{tabular}{|c|c|}
\hline Systems Components & Description \\
\hline Stocks & $\begin{array}{l}\text { Stock variables accumulate the results of action within the system. For } \\
\text { example, inventory, number of employees. }\end{array}$ \\
\hline \multirow[t]{2}{*}{ Flows } & $\begin{array}{l}\text { Flow variables describe the rate of change over time of the stock variables. } \\
\text { For example, inventory turnover, employee turnover. }\end{array}$ \\
\hline & Stock and Flow variables must alternate in a systems diagram. \\
\hline Feedback Loops & $\begin{array}{l}\text { Consist of two or more linkages connected in such as way that, beginning } \\
\text { with any variable, one can follow the arrows around and return to the starting } \\
\text { variable. Feedback loops can either be reinforcing or balancing. Every system is } \\
\text { composed of both reinforcing and balancing loops. }\end{array}$ \\
\hline "Same" effect & $\begin{array}{l}\text { An increase (decrease) in one variable leads to an increase (decrease) in the } \\
\text { subsequent variable. Denoted with plus sign }(+) .\end{array}$ \\
\hline "Opposite" effect & $\begin{array}{l}\text { An increase (decrease) in one variable leads to a decrease (increase) in the } \\
\text { related variable. Denoted with a minus sign }(-) \text {. }\end{array}$ \\
\hline \multirow[t]{3}{*}{ Reinforcing (Positive) Loops } & $\begin{array}{l}\text { - Composed only of same effect relationships between variables or have an } \\
\text { even number of opposite effect relationships. }\end{array}$ \\
\hline & - Only act to amplify or accelerate an initial change of one variable. \\
\hline & $\begin{array}{l}\text { - Without constraints introduced by interaction with a balancing feedback } \\
\text { loop, a positive feedback loop produces only exponential change. }\end{array}$ \\
\hline \multirow[t]{3}{*}{ Balancing (Negative) Loops } & $\begin{array}{l}\text { - Act to counter the direction of initial change while seeking an equilibrium } \\
\text { or target goal. }\end{array}$ \\
\hline & - Have both same and opposite effect relationships between variables. \\
\hline & - Have an odd number of opposite effect relationships. \\
\hline Delays & $\begin{array}{l}\text { Interruptions between a change in one variable and its effect on a linked } \\
\text { variable. }\end{array}$ \\
\hline Gaps & $\begin{array}{l}\text { Help identify appropriate actions for an organization by revealing where an } \\
\text { actual state differs from a desired state, where the system does not currently } \\
\text { achieve the objective of an organization within the system. }\end{array}$ \\
\hline Leverage Points & $\begin{array}{l}\text { Actions or a series of actions that can have a significant impact on the system. } \\
\text { Often small, or overlooked, actions have the most impact on the system, by } \\
\text { focusing managerial resources on specific efforts. }\end{array}$ \\
\hline
\end{tabular}

\section{The Case of Norm Thompson Outfitters' Pursuit of Environmental Sustainability}

\section{Company Background}

Norm Thompson Outfitters, headquartered in Hillsboro, Oregon, is a privately held consumer catalog company. Founded in 1949, the company originally focused on fly-fishing gear and evolved into a supplier of high-end outdoor gear, specialty home products, and high-quality apparel. NTO's current chairman, John Emrick, joined the company in 1965, overseeing the transformation of NTO in a number of key strategic areas: from a subsidiary of Parker Pen to his own ownership; from a single catalog targeting sports enthusiasts to four catalogs offering a wide range of products, including casual and outdoor clothing, 
TABLE 2. How to Build a Systems Dynamics Diagram—Using NTO's Recycled Paper Initiative, Focusing on the Recycled Quality Variable

\begin{tabular}{|c|c|c|}
\hline Step & Description & Examples \\
\hline I. & $\begin{array}{l}\text { Define the } \\
\text { Problem }\end{array}$ & $\begin{array}{l}\text { Printing high-quality catalogs consumes massive amounts of virgin wood pulp. } \\
\text { Printing on recycled paper may result in lower quality printing. }\end{array}$ \\
\hline 2. & $\begin{array}{l}\text { Identify the Key } \\
\text { Variables }\end{array}$ & $\begin{array}{l}\text { Print quality when using recycled paper. Perceived print quality. Demand for } \\
\text { recycled paper. Industry investment in recycled content technology }\end{array}$ \\
\hline 3. & $\begin{array}{l}\text { Describe How } \\
\text { the Key Variables } \\
\text { Behave OverTime }\end{array}$ & $\begin{array}{l}\text { Print quality increases. Perception of print quality is low, and change is unknown. } \\
\text { Demand for recycled paper fluctuates, with a slow upward trend. Industry } \\
\text { investment in technology fluctuates both up and down. }\end{array}$ \\
\hline 4. & $\begin{array}{l}\text { Identify Causal } \\
\text { Links between } \\
\text { Variables }\end{array}$ & $\begin{array}{l}\text { As print quality increases, the perception of print quality increases. As the } \\
\text { perception of print quality increases, demand for recycled content increases. } \\
\text { As demand increases, investment in technology increases. As investments in } \\
\text { technology increases, print quality increases. }\end{array}$ \\
\hline 5. & $\begin{array}{l}\text { Identify the Gaps } \\
\text { in the Systems }\end{array}$ & Demand for recycled content is less than the desired demand. \\
\hline 6. & $\begin{array}{l}\text { Identifying the } \\
\text { Leverage Points }\end{array}$ & $\begin{array}{l}\text { Perceived quality of catalogs printed on recycled paper is low. Actual effects of } \\
\text { using recycled paper are unknown.--Leverage point is the perceived quality of } \\
\text { printing with recycled content paper. }\end{array}$ \\
\hline 7. & $\begin{array}{l}\text { Determining } \\
\text { Actions Steps }\end{array}$ & $\begin{array}{l}\text { Determine the response of customers when they are sent catalogs with recycled } \\
\text { content. Communicate the results of the test. These steps will improve the } \\
\text { accuracy of the perceptions of print quality. }\end{array}$ \\
\hline 8. & $\begin{array}{l}\text { Test Systems } \\
\text { Model through } \\
\text { Simulation, } \\
\text { Prototypes, or } \\
\text { Other Methods }\end{array}$ & $\begin{array}{l}\text { With the assistance of the Alliance for Environmental Innovation, conduct a } \\
\text { controlled experiment to test the response of customers to recycled content. } \\
\text { Report the results in publications, news releases, and at roundtable discussions } \\
\text { at meetings. }\end{array}$ \\
\hline
\end{tabular}

unique gifts, and gourmet foods. NTO employs 675 people and its 2001 annual sales were \$200 million. The company's activities include market research, product testing and procurement, catalog design and distribution, and sales and aftersales service. In addition to its four catalogs, NTO offers its full line of goods through six retail stores and three web sites.

In 1992, Emrick had a self-described "coming out" as an environmentalist, but was uncertain about the possibilities of managing a firm in both a financially and environmentally sound manner. As member of the Young Presidents networking group, a global organization of business leaders, ${ }^{13}$ Emrick invited Paul Hawken to speak at the annual meeting. Hawken's ideas, introducing the possibilities of a commercial system based on environmental and socially sound principles, energized Emrick to move his company to be more environmentally responsible. He embraced the idea of a company that was economically viable, environmentally responsible, and socially active-the triple bottom line of sustainability. 
TABLE 3. Timeline for Norm Thompson Outfitters' Corporate Environmental Strategy

\begin{tabular}{ll}
\hline Early 1990s & CEO Emrick identifies environmental stewardship as key strategic thrust for NTO \\
\hline 1994 & "Green" building constructed \\
\hline 1998 & The Natural Step training initiated for all employees \\
\hline July 1999 & Corporate Sustainability Manager hired \\
\hline 2000 & Sustainability Action Plan formalized \\
\hline 2001 & Focus on Paper \& Forestry and Climate Change objectives \\
\hline 2002 & Focus on Merchandising And Packaging objectives \\
\hline
\end{tabular}

To be a leader for sustainability, Emrick first decided to ensure that his company had a supportive culture and a clearly articulated and shared vision. Table 3 provides a timeline showing the corporate level activities that focused on building an environmental sustainability-oriented culture and vision. In 1994, NTO built a new "green" corporate headquarters. This was the first commercial building in Oregon that met Portland General Electric's Earth Smart Gold Standards. Although the building garnered some media coverage, the primary communication was to NTO employees, signifying management's vision of environmental sustainability and its determination to act on this vision. The building was also a clear demonstration that the pursuit of environmental sustainability can be financially beneficial. The additional cost of creating a "green" building was paid back through energy savings in less than four years.

To truly impact the corporate culture, however, NTO's management knew that the employees must not simply see the vision, they must also understand the vision. To begin to address this issue, all NTO employees received training from The Natural Step (TNS), an organization that uses a scientifically derived framework to direct firms toward improving environmental impact and social equity. Since 1998, every employee at NTO attends TNS training within 6 months of being hired. This training creates a baseline for a shared mental model of what environmental sustainability means, why it is important, and how it relates to the business of the company.

Finally, in 1999, Emrick hired Derek Smith into the newly created Corporate Sustainability Manager position. Smith's job was to provide a single point of accountability for NTO's sustainability initiatives. Within the organization, the hiring of Smith raised the visibility of sustainability, centralized sustainability efforts, and created accountability at the management level for sustainable initiatives.

In 2000, Smith introduced a corporate environmental sustainability Action Plan. The Action Plan identified five areas that NTO believed it could have the most significant impact on: products, packaging, publishing (including catalogs), transportation, and influence. The Action Plan set forth ambitious 5 -year goals in each of these areas. The stretch goals included: no net greenhouse gas impact, elimination of specific toxins (e.g., formaldehyde, PVC) from 
products and processes, no negative forestry impact, and elimination of waste in facilities. Smith viewed these stretch goals as essential early steps in the quest for environmental sustainability.

NTO's Action Plan provided direction to management and employees and identified specific factors to consider when making decisions. In order to achieve these goals, NTO needed to identify and activate specific leverage points in the systems defined by the "problems" of specific strategic environmental sustainability initiatives. Table 4 provides timelines for the key steps taken in two discrete initiatives within NTO, adoption of recycled content paper for catalog production and modifying the merchandising activity to increase the environmental sustainability of products sold through the catalogs. Emrick and Smith recognized that although these initiatives only represented small steps, they were nonetheless steps forward in their pursuit of environmental sustainability.

\section{NTO's First Environmental Sustainability Initiative: Increasing Usage of Recycled Content}

With its massive consumption of paper for printing and packaging, the catalog industry has many opportunities to modify its practices to enhance environmental sustainability. NTO's goal of no negative forestry impact hits at the heart of the company's and the entire catalog industry's traditional modus operandi. ${ }^{14}$ NTO recognized that using recycled paper for catalogs throughout the industry would reduce the impact on forests. Any change in the type of paper for catalogs, however, is a highly sensitive issue. With response rates averaging only 3 percent, industry players resist any changes in catalog presentation for fear that it might reduce responses. Furthermore, the price for acceptable quality of paper with recycled content has historically been greater than for comparable virgin content paper. As a consequence, at the time of the formal release of NTO's Action Plan, recycled content was used to a very limited extent in NTO's sector of the catalog industry.

In late 1999, NTO converted one of its catalog lines, Early Winters, to $10 \%$ recycled content. This change was initiated without pre-testing potential impacts on response rates; and the move to $10 \%$ rather than another amount was arbitrary, as there was no empirical evidence that any percentage was more or less likely to be accepted by consumers. This change to recycled paper content was done without notifying the customers, although Emrick and Smith assumed that the primary target audience, predominantly outdoor enthusiasts, would react positively, if at all, to the change. Subsequently, the Alliance for Environmental Innovation, during the writing of its Greener Catalogs report, ${ }^{15}$ approached NTO to partner in a formal study of the use of recycled paper in catalogs. This provided NTO an opportunity to scientifically test the impact of recycled content paper on response rates.

NTO's requirements for recycled paper included four primary factors. First, there must be sufficient readily available recycled paper, in the necessary grades, weights, and quality. Second, the recycled paper could not cost more than the virgin paper already being used. Third, the paper must have the same 
TABLE 4. Timeline for Norm Thompson Outfitters' Environmental Sustainability Initiatives

\begin{tabular}{|c|c|c|}
\hline & \multicolumn{2}{|c|}{ Initiatives } \\
\hline & Recycled Content & Merchandising \\
\hline \multicolumn{3}{|l|}{1999} \\
\hline October-December & $\begin{array}{l}\text { Switched Early Winters catalog to } \\
10 \% \text { recycled content }\end{array}$ & $\begin{array}{l}\text { Senior management and buyers } \\
\text { toured organic cotton farms }\end{array}$ \\
\hline \multicolumn{3}{|l|}{2000} \\
\hline January-March & $\begin{array}{l}\text { Formed Agreement with Alliance } \\
\text { for Environmental Innovation (AEI) } \\
\text { to study impact of recycled content } \\
\text { on response rates }\end{array}$ & $\begin{array}{l}\text { Management committed to pur- } \\
\text { chasing organic cotton products, } \\
\text { phasing out PVC-based products }\end{array}$ \\
\hline $\begin{array}{l}\text { April-June } \\
\text { July-September }\end{array}$ & $\begin{array}{l}\text { Conducted recycled content- } \\
\text { response rate study with AEI } \\
\text { (through Spring 200I) }\end{array}$ & \\
\hline \multicolumn{3}{|l|}{ October-December } \\
\hline \multicolumn{3}{|l|}{2001} \\
\hline \multirow[t]{2}{*}{$\begin{array}{l}\text { January-March } \\
\text { April-June }\end{array}$} & \multicolumn{2}{|l|}{$\begin{array}{l}\text { Visited paper suppliers' de-inking } \\
\text { facility, mills \& forestry operations }\end{array}$} \\
\hline & \multicolumn{2}{|l|}{$\begin{array}{l}\text { Convened Industry Roundtable } \\
\text { to share results of study with } \\
\text { competitors \& suppliers }\end{array}$} \\
\hline July-September & \multicolumn{2}{|l|}{$\begin{array}{l}\text { Converted Solutions catalog to } \\
10 \% \text { recycled }\end{array}$} \\
\hline \multirow[t]{3}{*}{ October-December } & Concluded partnership with AEI & \multirow{2}{*}{$\begin{array}{l}\text { Buyers conveyed to management } \\
\text { their need for sustainability training } \\
\text { and performance evaluation }\end{array}$} \\
\hline & \multirow[t]{2}{*}{$\begin{array}{l}\text { Converted all catalogs to } 10 \% \\
\text { recycled content }\end{array}$} & \\
\hline & & $\begin{array}{l}\text { Developed concept of Sustainability } \\
\text { Scorecard and Toolkit }\end{array}$ \\
\hline \multicolumn{3}{|l|}{2002} \\
\hline \multirow[t]{3}{*}{ January-March } & $\begin{array}{l}\text { Conducted tests with higher } \\
\text { levels of recycled content }\end{array}$ & \multirow{2}{*}{$\begin{array}{l}\text { Held a series of brainstorm } \\
\text { sessions with buyers to develop } \\
\text { Sustainability Scorecard }\end{array}$} \\
\hline & \multirow{2}{*}{$\begin{array}{l}\text { Worked with paper merchant } \\
\text { to search for and negotiate with } \\
\text { alternative suppliers of paper }\end{array}$} & \\
\hline & & $\begin{array}{l}\text { Established baseline Sustainability } \\
\text { Scores for each buyer }\end{array}$ \\
\hline April-June & $\begin{array}{l}\text { Converted Solutions to I } 5 \% \text {; Early } \\
\text { Winters to } 20 \% \text { recycled content }\end{array}$ & $\begin{array}{l}\text { Launched Sustainability Scorecard } \\
\text { with training sessions for buyers }\end{array}$ \\
\hline
\end{tabular}

print performance, such as color reproduction and runnability, as virgin paper. Finally, there could be no negative consumer response, in either the number or the size of the orders, from the catalogs with recycled content. 
NTO understood that movement to recycled content paper required more than anecdotal or faith-based support. It decided, with the cooperation of Alliance, to test the recycled content paper with actual catalog distributions. Starting in the summer of 2000 and through the spring of 2001, catalogs were printed and distributed on both virgin paper and recycled content paper. The Alliance supported this effort with a variety of activities, including overseeing the printing quality, assisting in finding suppliers, and in analyzing the response and sales data from the two types of paper.

NTO worked with one of its paper suppliers to ensure that there would be an adequate supply of the required quality paper. The paper supplier adapted its processes to meet the needs of NTO, and the two companies negotiated a price for the recycled paper. The Alliance and the paper supplier ran a series of tests to ensure that the recycled content paper met the requirements for normal printing. ${ }^{16}$ After these tests established that there were no production-side issues, NTO printed catalogs, some with recycled content, some with only virgin content.

NTO issued nine test catalog mailings, with a combined mailing size of over 2.4 million, comparing the differences in sales of catalogs printed with virgin paper to those using 10 percent recycled paper. The only difference between the catalogs was the paper. The Alliance and NTO collected data on all responses, and with a high level of statistical significance, the type of paper had no negative effects on product sales or response rates. Of the tests run, the only statistically significant difference was one test in which the recycled content catalog showed a slightly higher response rate than the virgin content catalog. NTO concluded that customer response was not affected by the change to recycled paper, and by October 2001 all of NTO's catalogs contained at least 10\% recycled content. Further tests continued, without the partnership of the Alliance, into early 2002. By midyear of 2002, two of the three active catalog lines were increased from $10 \%$ recycled to between $15 \%$ and $20 \%$ recycled content. Smith intends to continue to increase the recycled content of all catalogs, as long as it can be shown that there is no negative effect on sales; concurrently he is searching for sources of virgin content harvested from certified sustainably managed sources to meet NTO's additional requirements.

Beyond the internal changes in the catalogs, the company has actively promoted the use of recycled content in the industry. NTO employees and members of the Alliance organize presentations at catalog conventions, host roundtable events for catalog executives, and issue press releases regarding the use of recycled content paper. The Alliance published reports and wrote articles for trade journals and continues to promote the use of recycled content paper by using NTO as a business case.

The efforts of NTO have had some, albeit small, effect on other members of the catalog industry. It effectively showed that print quality, even with very high quality catalogs, can be maintained with recycled content paper. NTO negotiated a deal with one of its paper suppliers to provide paper at a competi- 
tive price. It is continuing to influence the industry by promoting its success. While currently there is weak demand for the recycled content paper NTO is using, as the demand grows, paper suppliers will increase production leading to lower per unit costs. Both the Alliance and NTO are working to increase the demand. Currently, their influence is small, but growing, according to both NTO's paper broker and Alliance representatives. According to NTO's paper broker, NTO's experience is beginning to influence smaller catalog companies in the Northwest. In addition, when NTO's paper supplier is producing recycled content paper for NTO, the paper is of sufficiently high quality that it is sold to other companies, which are concerned only with paper quality, irrespective of its recycled content.

Figure 1 presents a system diagram based on discussions with Smith, a representative from the Alliance, and NTO's paper broker.

\section{Problem Definition}

NTO's goal of no negative forestry impact demanded reductions in the amount of virgin wood used for the massive amounts of paper used by the company. Utilizing recycled paper provided the opportunity to reduce demand for virgin content.

\section{Variable Identification}

The system for inclusion of recycled content paper in the catalogs included five stock variables: overall demand for recycled content, the scope and scale of recycled content paper production, the quality of recycled paper, the supply of raw materials for recycled paper, and the return on investment for recycled paper technology. We also identified six flow variables: the price of recycled content paper, the perception of quality of recycled content paper, the paper industry investment in recycled content paper technology, raw material cost, the effectiveness of used paper collections, and the rate of change in paper quality due to technological advances. The flow variables affect the levels of the stock variables.

\section{Variable Changes and Causal Links}

Overall demand for recycled content was affected by two factors: the perception of the quality of recycled paper (as quality affects sales performance); and the price differential between recycled paper and virgin paper. The overall demand for recycled content directly affects the industry investment in recycled paper technology, which increases the scope and scale of recycled production. Increases in the scale and scope of recycled content decreases price, increasing demand and closing one reinforcing loop. Increased investment in recycled paper technology also increases the recycled content paper quality, which increases the perception of sales performance due to quality, leading to increased demand. This closes the second reinforcing feedback loop. 


\section{Balancing Loop Identification}

Two balancing feedback loops are apparent in the system. The first relates the achieved recycled content quality to the return on new investments in technology. As quality increases the rate of change in recycled content decreases (an opposite effect, noted with a minus sign in the systems diagram), following the law of diminishing returns. In other words, the amount of quality improvement for each additional increment of investment decreases. As the rate of change decreases, the incremental return on investment decreases (a same effect, noted with a plus sign in the systems diagram), subsequently reducing the industry's new investment in recycling technology. This reduction leads to fewer additional investments in recycled paper production processes. This completes the first balancing feedback loop.

The second balancing feedback loop associates the supply of raw materials for recycled paper to the scope and scale of recycled content production. As the scope and scale of production increases, the effectiveness of collection efforts (a flow variable) decreases. This means that it becomes increasingly difficult to collect post-consumer recycled paper, as the demand for recycled content raw material increases. The effectiveness of collection efforts directly affects the supply of raw materials for recycled paper. The supply of recycled paper, a stock variable, has an opposite effect on the cost of recycled paper raw material (a flow variable). Closing this feedback loop, the cost of recycled raw materials has an opposite effect on the scope and scale of production, as an increase in price will decrease the quantity of production.

\section{Leverage Point Identification}

Figure 1 shows NTO's efforts to change the system condition and structure related to recycled paper content. NTO recognized a demand for recycled paper content in its catalogs. While the target content level had not been absolutely established (and is not to this day), Smith knew that some recycled content, up to the point that sales would be affected negatively, was desired. This created a gap between the target level and the actual level. Although NTO was not explicitly using system dynamics, it identified relevant leverage points in the system and in taking appropriate action at these points attempted to close the gap.

NTO identified two leverage points where it felt it could affect the system: the recycled content price differential and the perceived recycled content quality. NTO assumed it could influence the first (price) through negotiation. This effort would be idiosyncratic to NTO, but would show that price parity could be obtained in some situations.

The second leverage point, perceived quality, was a characteristic that was amenable to testing and would be constant across all companies producing similar catalogs. NTO hypothesized that the perceived quality of recycled content could be changed by scientifically testing the actual responses to recycled paper by customers and by publicizing the results of the tests. Figure 1 shows the 
FIGURE I. Recycled Paper Content in the Catalog Industry

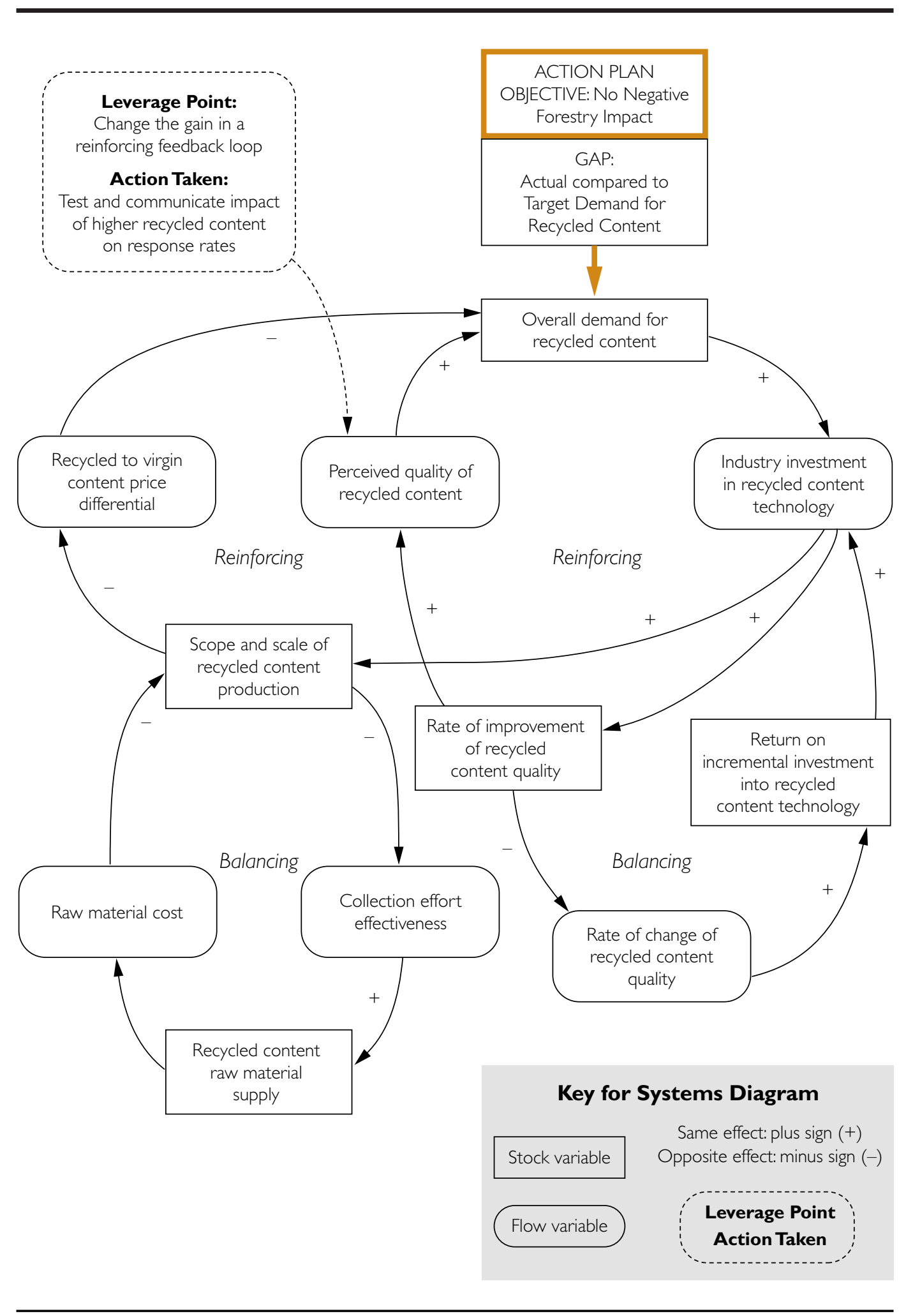


leverage point (perception of quality) and the action taken at that point (testing and communicating the actual response rates to industry constituencies).

NTO identified the factors affecting the gap in the system and addressed them. While NTO did not use systems diagrams to analyze its options prior to addressing the Action Plan, these diagrams help us understand its activities and results. Careful consideration of the gaps and variables in a relevant system can lead to identification of the leverage points in the system and to discovery of the actions to affect the lever.

As a result of applying pressure at the two leverage points, NTO achieved impressive results. Negotiations with paper suppliers led to a pricing arrangement that put recycled paper on par with virgin paper for the catalogs. NTO now produces all its catalogs with a minimum of $10 \%$ post-consumer recycled content. In addition, NTO's experimental efforts provided knowledge to decrease the gap between target and actual levels of demand. The knowledge about response rates will allow other firms, with similar desires to increase their usage of recycled paper, to do the same.

NTO estimates that its move to recycled paper has already saved 4,400 tons of wood, 20 billion BTUs of energy, and 990 tons of solid waste. NTO's leadership in testing the results of using recycled paper has shown that the move to recycled paper does not affect sales and has positive effects on environmental sustainability. Both Smith and the Alliance for Environmental Innovation have actively promoted these results through industry roundtables, press releases, and a number of environmental management-oriented web sites (e.g., GreenBuzz.com). NTO's desire to be a leader, rather than to just make internal changes, stems from a systemic view of environmental sustainability. NTO's explicit objective is to influence other catalog companies to use recycled content, in effect increasing the scale economies for the paper producers and further reducing the costs of recycled content to match or beat virgin material. NTO utilized the leverage point where it could influence other companies by examining the issue systemically and choosing a factor it could influence.

Table 2 describes the steps NTO could have used to explicitly identify the important variables and relationships relating to a small part of the recycling initiative system, the perception of print quality. Although NTO arrived at its actions intuitively, the use of systems thinking (as outlined in Table 2) could have led NTO to the leverage points it sought in a more structured, purposeful manner. The systems diagram now may serve as an iterative planning tool for NTO as it considers options for continually reducing its environmental impact of its catalogs.

\section{NTO's Second Environmental Sustainability Initiative: Reducing the Environmental Impact of Merchandising}

Although significant, the first steps in pursuit of environmental sustainability were relatively simple compared to the task of addressing the environmental impact of the company's merchandising. Since NTO neither designs nor manufactures most of the products it sells, it maintains limited direct control 
over product development and production activities. Furthermore, across its catalogs, the products span from apparel to household items, presenting a product range consisting of various materials and processes that may be environmentally unsustainable. This product range created a significant challenge for NTO to meet its goal of eliminating toxins from its products and processes. NTO could only impact the environmental sustainability of the products it sells by putting sustainable products in its catalogs. In order to improve the environmental sustainability of its merchandising, NTO had to change the behavior of its buyers, inside the firm, and the behavior of its suppliers, outside the firm.

Traditionally, buyers have considerable autonomy at NTO. Management places boundaries on each catalog by target audience and product categories. For example, according to Amy Stoyanov, Merchandising Manager for the Solutions catalog, her buyers are restricted to offering "hard" household goods targeted to women. NTO management expects its buyers to meet sales and profitability standards and rewards the buyers based on total demand for the buyers' products, the sales per page-area of the buyers' products, and the gross margin of the buyers' products. These standards are financially based, and the buyers are familiar with the expectations and reward system in place. Within these parameters, buyers work independently to make actual product selections.

The ultimate objective of NTO's merchandising environmental sustainability initiative was to increase the sustainable products as a percent of total product sales. In October 1999, senior management and NTO buyers took the next step along this path by touring organic cotton operations. Satisfied that sufficient quality and quantity of organic cotton was available at an acceptable price, NTO committed to phasing out PVCs and introducing organic cotton into its soft goods lines. Unfortunately, initial results were disappointing, with little noticeable change in the products contracted for the catalogs, and by mid-2001 it was recognized that NTO lacked a clear strategy.

In August 2001, Emrick and Smith convened an off-site meeting with the merchandising managers and buyers. At the meeting, Smith presented a one-page informational sheet identifying several characteristics of environmental sustainability, such as organically grown fiber and non-toxic dyes. Management's objective was to encourage buyers to choose products that met at least 3 of these environmental sustainability characteristics. Management felt that general guidance to buyers on sustainable purchasing would result in merchandising becoming increasingly sustainable.

Philosophically, the buyers were strongly supportive of the corporate vision of environmental sustainability and, in turn, of using environmental sustainability to evaluate products. According to Stoyanov, the buyers on the Solutions team as well as those on other catalog teams were firmly committed to reducing the environmental impact of the products offered. However, there were two problems. First, even with the informational sheet in hand, the buyers did not have the ability to identify environmental sustainability product attributes. Second, some of the buyers did not see the corporate-level vision for environmental sustainability as congruent with the individual buyers' reward 
FIGURE 2. Stages of Life Cycle Analysis of Cotton from NTO's Sustainability Toolkit

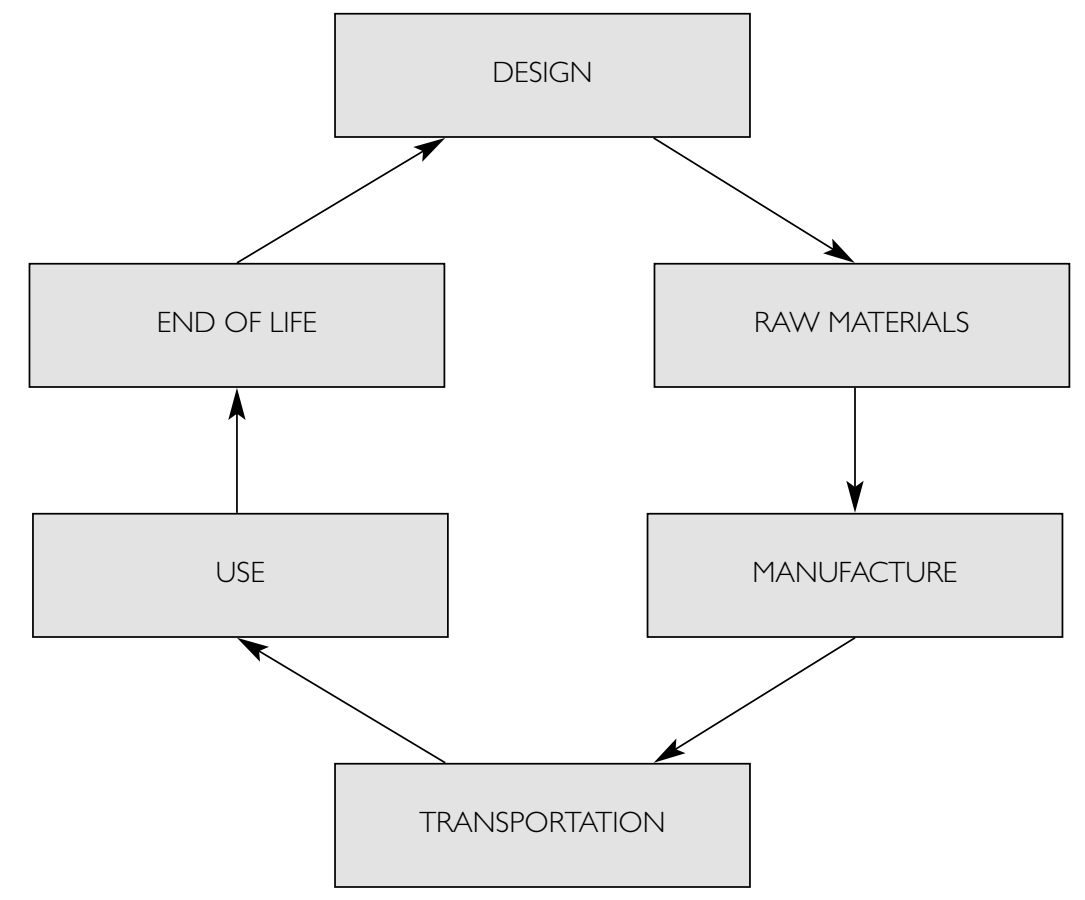

(๔) Norm Thompson Outfitters and Michael Brown \& Associates. To view the entire Sustainability Toolkit and Scorecard, please go to www.bsr.org.

systems. Although they were told that environmental sustainability criteria were valued, the reward system still reflected solely financial results.

To address these issues, NTO management hired Michael Brown \& Associates, an environmental consulting firm, to develop a Sustainability Toolkit. Because the buyers knew the attributes of the products in their portfolios best, NTO management ensured that they were involved in developing the Toolkit. The Toolkit identified major types of products and potential product materials. Life-cycle analyses of products were conducted to assess each product's environmental impact from "cradle-to-grave." From this consideration, sourcing preferences were generated for specific materials used in the products, and a scoring system was developed ranking types of materials from +3 to -3 . Figures 2 and 3 show the stages of life-cycle analysis and the sourcing preferences worksheet for cotton. The sourcing preferences worksheet shows the process for examining a clothing line, where materials made of organically grown cotton received a higher score than traditionally grown cotton, which scored higher than a genetically modified product. A series of training workshops were conducted with the buyers on all catalog teams on how to use the Toolkit to analyze products. 
FIGURE 3. Sourcing Preferences from NTO's Sustainability Toolkit

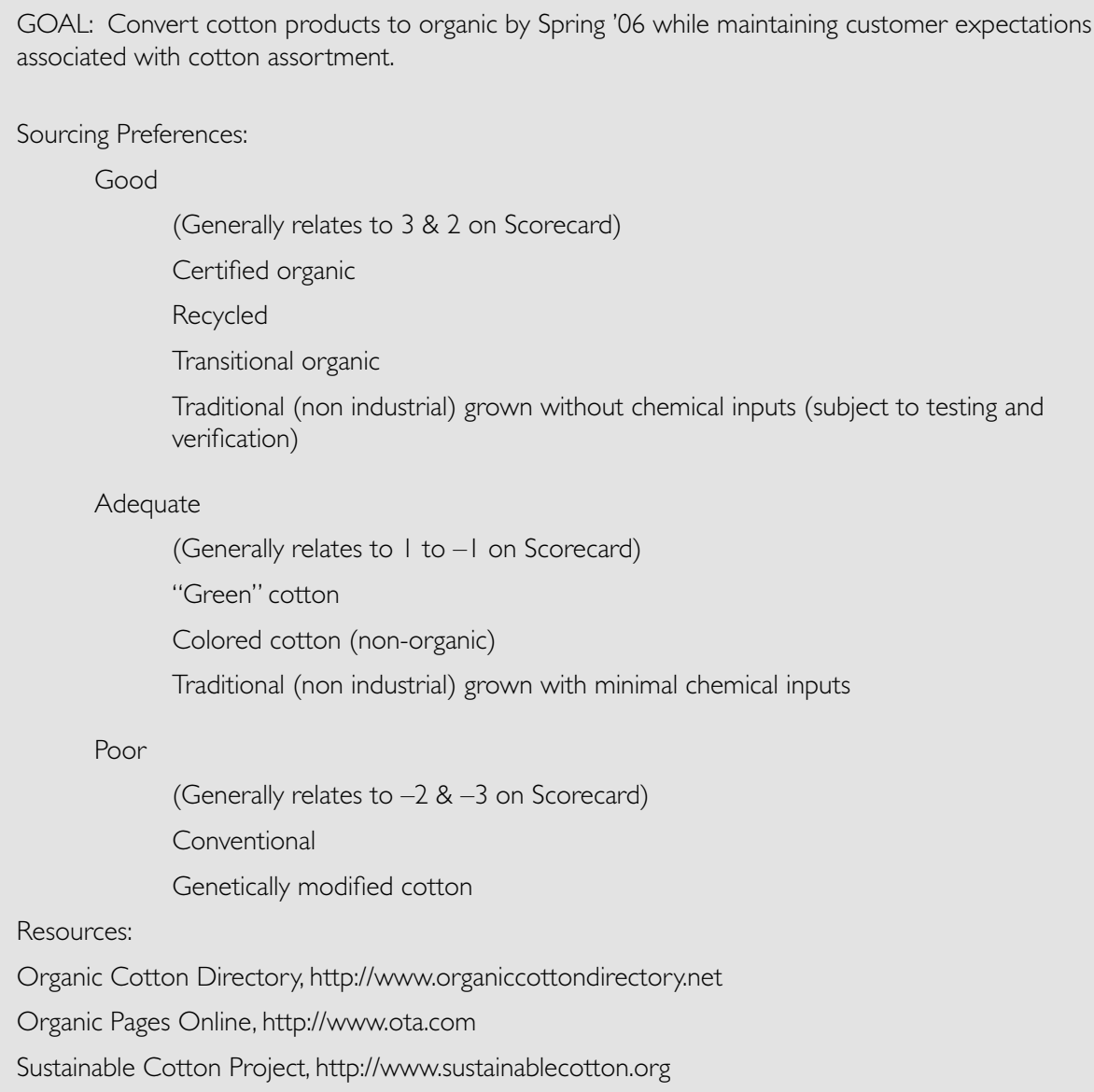

(c) Norm Thompson Outfitters and Michael Brown \& Associates. To view the entire Sustainability Toolkit and Scorecard, please go to wnw.bsr.org.

In conjunction with the Toolkit, management developed a Sustainability Scorecard for including product environmental sustainability into the evaluation and compensation schemes for NTO buyers. Figure 4 shows an example of the Scorecard for textile materials. The evaluation and compensation system includes a baseline sustainability score, changes in the scores over time, and an assessment of the change over time. Importantly, progress in sustainable buying is based on a relative measurement. The baseline reflects current product lines offered in a catalog evaluated using the environmental sustainability criteria and the opportunity for change determined through collaborative dialogue between the buyers and management. The opportunity for change differs among catalogs and among types of products within a catalog. 
FIGURE 4. Evaluation System from NTO's Sustainability Scorecard

\begin{tabular}{|c|c|c|}
\hline Score & Examples of Materials & Criteria \\
\hline & $\begin{array}{l}\text { Organic cotton, organic silk, } \\
\text { organic wool, organic hemp, organic } \\
\text { leather (hide and tanning) }\end{array}$ & $\begin{array}{l}\text { - Materials without hazards across life cycle } \\
\text { - Natural materials produced in sustainable } \\
\text { manner } \\
\text { - Biodegradable and/or easily recyclable }\end{array}$ \\
\hline & $\begin{array}{c}\text { Recycled polyester, recycled wool, } \\
\text { recycled cotton, latex, } \\
\text { hemp/linen (natural retting), } \\
\text { organic cotton/RCR polyester }\end{array}$ & $\begin{array}{l}\text { - Materials with minor hazards in life cycle } \\
\text { but no carcinogens } \\
\text { - Moderate recycled content } \\
\text { - Biodegradable and/or potentially recyclable }\end{array}$ \\
\hline & $\begin{array}{c}\text { Tencel, conventional silk, silk/cashmere, } \\
\text { hemp/linen (chemical retting), ramie, } \\
\text { organic cotton/polyester }\end{array}$ & $\begin{array}{l}\text { - Materials with some hazards in life cycle, } \\
\text { but no carcinogens } \\
\text { - Recycled content } \\
\text { - Downcyclable }\end{array}$ \\
\hline & $\begin{array}{c}\text { Vegetable-tanned leather, conventional } \\
\text { wool, polypropylene, silk/wool, down, } \\
\text { Tencel/acetate }\end{array}$ & $\begin{array}{l}\text { - Materials with moderate hazards in life cycle, } \\
\text { but no carcinogens } \\
\text { - Virgin/recycled content } \\
\text { - Moderate ecosystem impacts }\end{array}$ \\
\hline & $\begin{array}{c}\text { Conventional cotton, polyester, } \\
\text { nylon, acrylic, acetate, Tencel/cotton, } \\
\text { cotton/silk }\end{array}$ & $\begin{array}{l}\text { - Materials with significant hazards in life cycle, } \\
\text { but no carcinogens } \\
\text { - Virgin content } \\
\text { - Significant ecosystem impacts }\end{array}$ \\
\hline & $\begin{array}{l}\text { Chrome III-tanned leather, rayon, } \\
\text { viscose, acetate/ciscose/cotton, } \\
\text { peoprene, spandex } \\
\text { and spandex blends }\end{array}$ & $\begin{array}{l}\text { - Materials with significant hazards in life cycle, } \\
\text { but no carcinogens } \\
\text { - Virgin content } \\
\text { - Significant end-of-life issues }\end{array}$ \\
\hline & PVC, chrome VI-tanned leather & $\begin{array}{l}\text { - Materials with extreme hazards (endocrine } \\
\text { disrupters, carcinogens, etc.) in life cycle } \\
\text { - No biodegradable or recyclable content }\end{array}$ \\
\hline
\end{tabular}

(C) Norm Thompson Outfitters and Michael Brown \& Associates. To view the entire Sustainability Toolkit and Scorecard, please go to www.bsr.org.

NTO management purposefully designed the reward and product-ranking systems of the Scorecard and Toolkit to maintain the buyers' autonomy and at the same time provide sufficient information to guide individual buyer decision making toward achieving the Action Plan objectives. To complete the connection between the environmental sustainability objectives for merchandising and buyer decision making, NTO management altered the existing compensation 
scheme so that the determination of buyers' annual raises is based $10 \%$ on the improvements in their sustainability scores, and $90 \%$ on financial criteria.

Introduction of the Toolkit and Scorecard and adjustment in the compensation system addressed internal issues. Full implementation of these initiatives, however, affected NTO's supplier relations. The move towards a greater environmental sustainability product portfolio necessitated changes in supplier behavior. Buyers were encouraged to share the Toolkit and Scorecard with suppliers, educating them on the environmental impact of select materials. ${ }^{17}$ Through collaborative efforts, buyers and suppliers were to search for and incorporate materials and processes that move the products up in Scorecard ratings. Educating themselves and their suppliers on the Toolkit and Scorecard placed additional burdens on the buyers and suppliers above and beyond the usual demands of the job. However, over the initial six months, there has been only one case of strong supplier resistance to the environmental sustainability efforts, according to Stoyanov. She cites many instances of suppliers' willing attempts to make product design changes. For example, through a consultative approach between NTO and one of its major suppliers, the supplier changed the composite material of its chair protectors, originally made entirely of polyvinyl, to a less toxic plastic material. This change provided an improvement in Sustainability Scorecard rating from a -3 to a -1 ; in addition, the supplier now manufacturers all of its chair covers in this manner, creating substantial environmental benefit beyond the sales to NTO.

The development of the Scorecard and Toolkit provided several benefits to the buyers. First, the values of each product attribute are unambiguously ranked. Second, the training workshops and criteria descriptions educate the buyers so that they can evaluate products not specifically addressed in the Scorecard. Third, it provides support for explaining purchase decisions with suppliers or potential suppliers. Fourth, the buyers can assess their own progress toward providing more sustainable products. Finally, it created a high level of congruence between the goals of the merchandising initiative and the corporate vision of environmental sustainability. Overall, the implementation of the Scorecard and Toolkit represents a critical step in achieving NTO's 2005 environmental sustainability objectives.

Systems dynamics and the use of systems diagrams can illustrate the leverage points directed at implementation of the merchandising sustainable initiative. Figures $5 \mathrm{a}$ and $5 \mathrm{~b}$ illustrate systems diagrams of merchandising that were developed through extensive discussions between the authors, Smith, Stoyanov, and other NTO employees after the Toolkit and Scorecard had been in operation for approximately six months. Figure 5a represents the relationships between merchandising and suppliers prior to the initiation of the Toolkit and Scorecard. Figure 5b shows how the system structure and condition were influenced through specific leverage points based on the environmental sustainability-focused initiatives. Separating Figures $5 \mathrm{a}$ and $5 \mathrm{~b}$ shows that systems dynamics modeling can be applied at any stage in a firm's pursuit of sustainability. Prior to the time that NTO decided to address merchandising as an 
FIGURE 5A. Systems Diagram of NTO's Merchandising

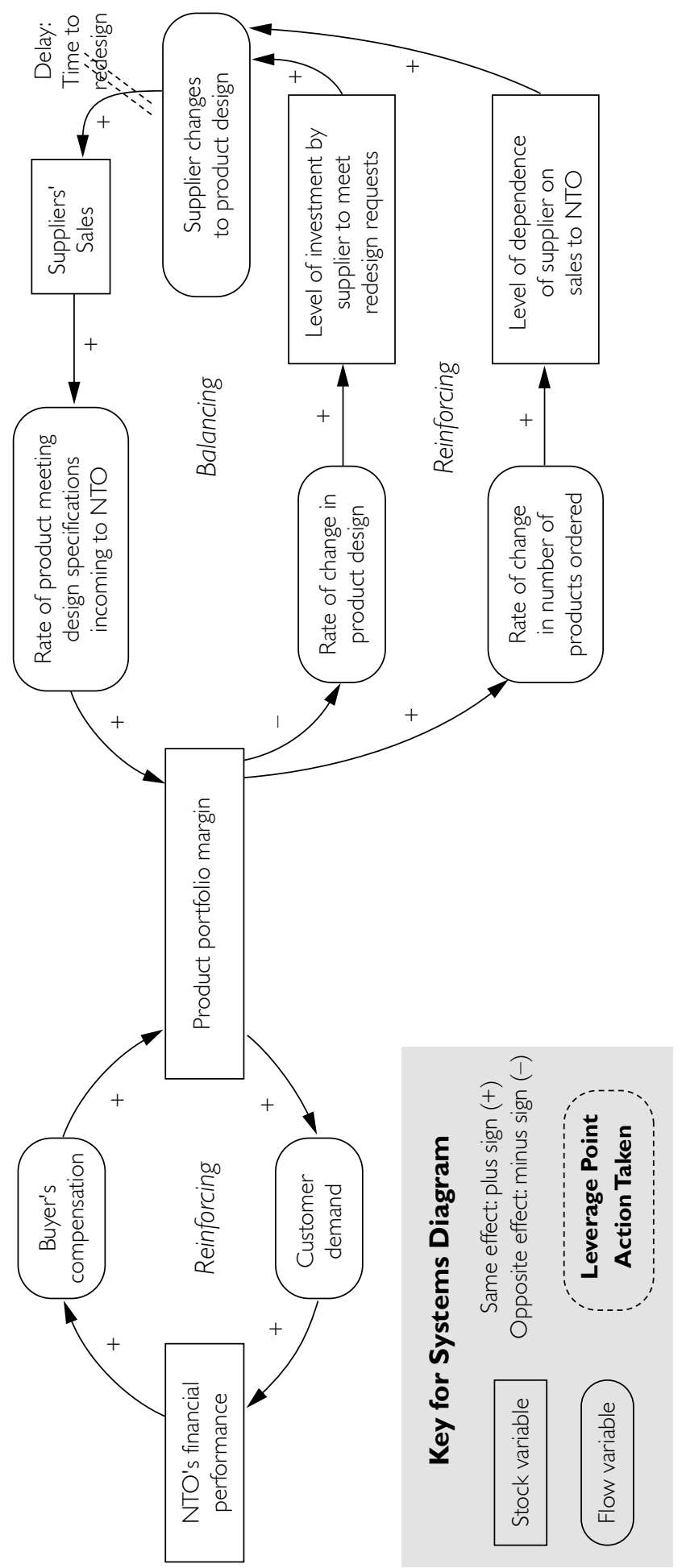


FIGURE 5B. Systems Diagram of NTO's Environmental Sustainability Merchandising Initiative

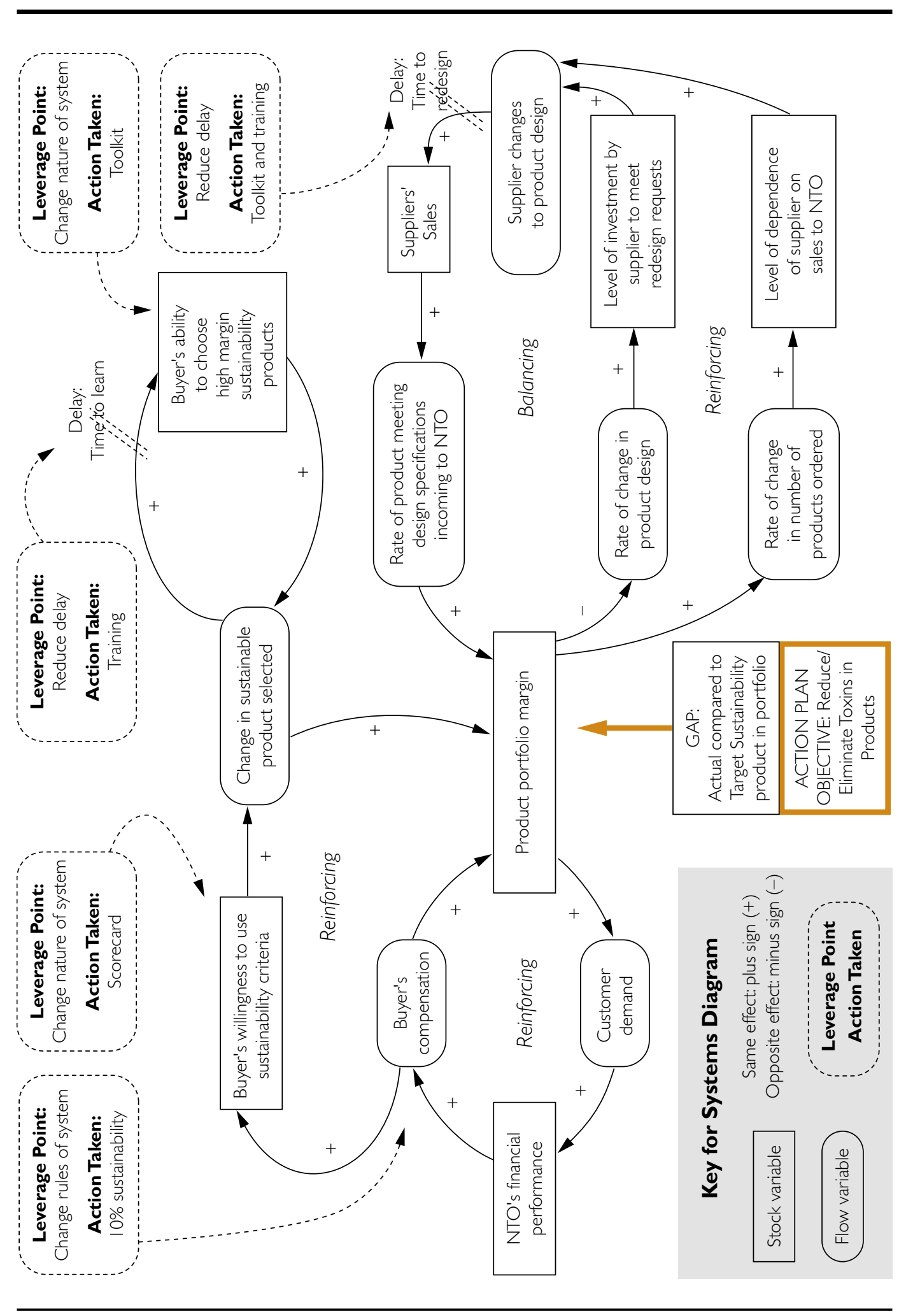


environmental sustainability initiative, its vision of the merchandising system could have been diagramed as shown in Figure 5a. ${ }^{18}$ Using this initial diagram, planners at NTO could identify the gap where the desired goal of an environmentally sustainable product portfolio differed from the actual product portfolio. By analyzing the gap, it becomes apparent that Figure 5a is an incomplete picture of the system. Inclusion of environmental sustainability as a factor in the system forces the analyzer to consider other system components, which are the feedback loops included in Figure 5b.

\section{Problem Definition}

From NTO management's perspective there had not been sufficient progress in meeting the Action Plan objectives regarding reduction of toxins in product offerings.

\section{Variable Identification}

Two key stock variables were identified in the merchandising program prior to the environmental sustainability efforts: the contribution margin of the buyers' product portfolios ${ }^{19}$ and NTO's financial performance. In addition, two flow variables were identified: customer demand for products offered in the catalogs and the compensation received by NTO buyers.

From the suppliers' perspective, we noted three stock variables: the investment by the supplier to make product redesign changes, the level of dependence of the supplier on sales to NTO, and the supplier's sales to NTO. Four flow variables were also identified, including: the rate of change in product design, the rate of change in the number of products ordered by NTO, supplier's changes to its product offering, and the rate of incoming product meeting NTO's design specifications.

\section{Variable Changes and Causal Links}

In the merchandising program, as the product portfolio of buyers focused on higher margin and higher demand products, consumer demand rose, leading to an increase in NTO's financial performance and enhanced compensation for the buyers. In turn, buyers were inclined to continue selecting products on the basis of high margin/high demand.

In regards to supplier relations, the greater the rate of change in desired product attributes for orders placed by NTO, the higher the amount of investment the supplier will need to make to meet the redesign requests. The more the suppliers invest in redesign, the higher the rate of actual product changes, leading to increasing supplier sales and a higher rate of incoming product to NTO meeting its design specifications. This creates a balancing loop in the system.

NTO also needs to consider the volume purchased from the supplier and how much the supplier depends on NTO. Thus, the product portfolio margin will drive the rate of ordering from the supplier. The rate of change in the number of product orders will be positively related to the level of dependence the supplier 
has on sales to NTO. Furthermore, the higher the level of dependence, the more likely the supplier will meet NTO's product design requests. This creates a reinforcing loop in the system.

\section{Feedback Loop Identification}

The merchandising activities represent a reinforcing feedback loop, with all causal relationships between variables being same effects. The causal links in the supplier relationship variables represent one balancing feedback loop and one reinforcing feedback loop. The balancing feedback loop is characterized by an opposite effect between product portfolio margin and rate of change in product design. That is, the greater the margin in the portfolio, the less inclined NTO will be requesting product redesign. Importantly, there is a delay preceding supplier changes to product design. Suppliers' reconfiguration of sourcing activities and production processes commensurate with the requested product alterations will create delay in the actual accomplishment of these reconfigurations. The balancing and reinforcing feedback loops are illustrated in Figure 5a.

\section{Leverage Point Identification}

Figure 5b shows a systems diagram representing NTO's efforts to change the system condition and structure related to merchandising environmental sustainability. Figure $5 \mathrm{~b}$ shows a more complete view of the system, after considering environmental sustainability. This broader view incorporates the newly identified stocks and flows of the system and shows the system conditions as a result of the merchandising sustainability initiative. NTO can further use Figure $5 \mathrm{~b}$ as a planning tool as it considers its next steps in increasing the environmental sustainability of its product portfolio.

In Figure 5b, a gap is designated at the system condition-defining variable, NTO buyer's product portfolio margin. This gap signifies the disparity between the actual environmental sustainability and the target environmental sustainability of NTOs merchandising activities.

Next, compensation policy was identified as a leverage point in the system. Buyers were originally compensated solely on financial criteria. Compensating buyers on environmental sustainability as well as financial criteria requires a change in the rules of the system. This change is based on the belief that compensation schemes that include environmental sustainability criteria will help close the gap between actual and target environmental sustainability in the buyers' portfolios.

Two new stock variables and one new flow variable were added to the original diagram: buyers' willingness to use environmental sustainability criteria, buyers' abilities to find and place products with higher environmental Sustainability Scorecard ratings in catalogs, and change in the amount of environmental sustainability product selected by the buyers. These additional variables were added to address two leverage points identified in the system: influencing buyers' willingness to utilize environmental sustainability criteria through the introduction of the Scorecard; and impacting the buyers' abilities to assess and select 
products based on sourcing preferences provided through the Toolkit and associated training. These new variables changed the nature of the system by adding additional feedback loops, as shown in Figure 5 b. The system relationships created by these variables are: greater willingness of buyers to use environmental sustainability criteria will increase the flow of environmental sustainability product into the buyer's product portfolio and, in turn, increase the proportion of environmental sustainability product in the buyer's product portfolio; and, as buyers increase their knowledge about environmental sustainability product attributes, they will increase the rate of environmental sustainability product selection and, in turn, increase the proportion of environmental sustainability product in the buyer's product portfolio. Each of these systems relationships relates to the primary objective of decreasing the gap between actual and target environmental sustainability product in the buyers' portfolios.

Finally, two leverage points are highlighted in relation to reducing delays in the system. Training buyers and suppliers on the Toolkit and Scorecard reduces the time that it takes for them both to understand and incorporate environmental sustainability criteria into their decision making.

\section{Thinking and Acting Systemically}

In terms of environmental sustainability, an "ideal" sustainable organization will not use natural resources faster than the rates of renewal, recycling, or regeneration of those resources. ${ }^{20}$ Achieving this state of firm-natural environment interaction calls for systemic change. The application of systems dynamic models to the case of NTO highlights three key areas where this methodology proves valuable to the pursuit of environmental sustainability.

First, systems dynamics can help clearly delineate the relevant components (or, variables) involved in an environmental sustainability initiative and, importantly, identify their interrelationships.

NTO's merchandising initiative appeared simple in a number of respects. With a workforce committed to the principles of environmental sustainability and basic guidelines for qualifying environmental sustainability product attributes, NTO buyers would begin selecting products with lower environmental impact. However, there were a number of issues not addressed by this approach. A more comprehensive approach called for assessments and changes to employee training programs and compensation policies, supplier education and sourcing, and production methods. Merchandising environmental sustainability is a long-term proposition, with intermediate goals established through NTO's Action Plan. In continuing to move forward with its merchandising initiative NTO will need to repeatedly assess the evolving nature of the interrelationships between individual employees, departments, and its multitude of suppliers and how these interrelationships influence the system condition of product portfolio environmental sustainability. 
The complex nature of environmental sustainability makes identifying the key issues difficult. Problems or symptoms of unsustainable practices often require careful analysis in order to determine the cause of the problem or symptom. Systems dynamics looks for patterns of behavior. Modeling systems forces a manager to identify and articulate the system conditions, the actors, and the interrelationships between them that cause patterns of behavior. Systemic interdependencies are not easy to understand, nor are their implications for specific policies and strategies. As a systemic analysis proceeds, linkages between variables, gaps in targets and desired system conditions, and the location and extent of delays create a holistic and dynamic picture of strategic environmental sustainability issues. The systems diagrams represented in Figures 4 and $5 \mathrm{~b}$ can be used as a reference for learning how well the specific initiatives were implemented and as planning tools for NTO to continue its environmental efforts.

Second, systems dynamics can assist managers in identifying leverage points related to specific initiatives that facilitate systemic change.

Both strategic environmental sustainability initiatives examined in the NTO case highlighted the importance of leverage points in influencing systemwide change in behavior. The importance of perceptions of recycled content as lower quality was widely recognized. However, identifying the quality perceptions as a leverage point in the system was not necessarily intuitive, and proceeding with experimental trials to show the impact on response rates was not an obvious option. Whether the catalog industry will transform to a point where recycled content is universally used at high levels remains unclear. However, through its provision of statistical evidence of its experimental trials to industry constituencies, NTO disturbed the system so that substantive debate surrounding this issue is ongoing in the industry.

Systemic change is made possible through such small changes at key leverage points. Key leverage points that can create transformation are not always apparent in the planning of strategic initiatives. Because environmental sustainability initiatives are inherently complex-involving multiple conditions (financial, ecological, and social), stakeholder roles, attitudes and perceptions, as well as decision-making processes and information flows-a clear elucidation of the methods for moving these initiatives forward is essential. Systems dynamics tools enable the identification of the leverage points in the system. These can help a company plan and implement specific initiatives that influence system conditions, including its own and other systems actors' impacts on the natural environment.

Third, systems dynamics can help single out key stakeholders, both inside and outside the firm, and clarify their respective roles in implementing systemic change related to specific initiatives.

NTO's efforts to meet its forestry impact goals through increasing recycled content in its catalogs was dependent on close collaboration with the Alliance and NTO's paper supplier at the early stages of the process. NTO's goal 
of influencing systemic change in the catalog industry depends on its ability to continue to engage competitors as well as paper suppliers and merchants in changing perceptions of recycled content quality and raising demand. NTO's merchandising initiative calls for continued cooperation with suppliers and customers. Emrick and Smith both recognize that to implement future initiatives related to NTO's Environmental Sustainability Action Plan objectives they will need to continually reassess the potential roles of other key stakeholders and methods of securing and managing their cooperation.

Just as systems tools highlight the key issues for environmental sustainability, the tools help identify the key stakeholder groups and how they relate to the leverage points with respect to environmental sustainability initiatives. The systems dynamics approach takes an important next step in revealing how certain stakeholders should be involved in specific stages of the process of pursuing environmental sustainability for clearly identified purposes. On-going monitoring of system condition changes provides a manager the opportunity to distinguish new leverage points that emerge, and seek out stakeholders inside and outside the firm who will play essential roles in actuating these leverage points.

\section{Closing Thoughts}

A firm pursuing environmental sustainability needs to implement principles, policies, and practices, including job design, recruitment and selection, budgeting and reward systems, and organizational structures and stakeholder relationships, from the standpoint of long-term ecosystem viability. ${ }^{21}$ The process of moving the firm towards environmental sustainability requires establishing challenging stretch goals. As a result, in their attempts to introduce environmentally or socially oriented decision making across a firm, managers are often confronted with significant conflicts between the financial and the environmental and social considerations. A commonly shared corporate vision can provide clear direction in decision making, particularly when tradeoffs among goals become necessary. However, if people lack a common picture of the system within which they are operating, it is difficult, if not impossible, to align their actions. ${ }^{22}$ Systems dynamics provides managers a tool to envision the actionable steps to achieve the stretch goals and pursue the long-term vision of environmental sustainability. An environmental sustainability strategy remains challenging and complex, but developing systems dynamics models provides managers and employees a sense of how to pursue key initiatives within the context of a shared vision.

A systems dynamics approach is not unique in its ability to address any one of the three key areas outlined above, but it is distinctive in its facility at dealing with all three of these areas simultaneously. The strategy of environmental sustainability - as a "quest" characterized by complex challenges and an uncertain destination-requires holistic, dynamic, and analytical perspectives. Through clear articulation of problems, determination of root causes and key players, and identification of actionable steps to bring forth systemic change, 
systems dynamics is particularly well-suited for helping managers answer the question: How should environmental sustainability actually be pursued?

\section{APPENDIX Research Methodology}

We used a case study approach in applying systems thinking to the environmental sustainability initiatives undertaken by one firm. We conducted a series of personal interviews and in-depth archival data research over a sixmonth time frame. The interviews were conducted with the Sustainability Manager and other individuals in the company responsible for making key decisions about training, purchasing and strategic planning. In addition, interviews were conducted with a representative from the Alliance for Environmental Innovation, one of Norm Thompson's paper suppliers and one of its paper brokers. Each interview varied in length from 1 to $2 \frac{1}{2}$ hours, and in many cases individuals were interviewed multiple times. We also collected archival data over the sixmonth period from the firm concerning strategic planning, training programs, and purchasing criteria development. Finally, we performed in-depth secondary data collection related to the paper and catalog industries, suppliers, customers, and other relevant stakeholders.

\section{Notes}

1. From a roundtable discussion, in "Business as a Living System: The Value of Industrial Ecology" California Management Review, 43/3 (Spring 2001): 23.

2. The World Commission on Environment and Development, Our Common Future (New York, NY: Oxford University Press, 1987).

3. John Elkington, in his book Cannibals with Forks: The Triple Bottom Line of 21 st Century Business, is generally credited with popularizing the "triple-bottom-line" concept that suggests that corporate progress should be measured in terms of economic prosperity, environmental quality, and social justice. Since the publishing of this book, many corporations have adopted this approach as evidenced in their sustainability reports. For example, in its 2001/2002 Environmental Report, Volkswagen states "sustainability refers expressly to the fields of ecology, economics and social conditions." [p. 5.] Similarly, The Shell Report: People, Planet and Profits opens with "[t]his report documents the actions we have taken in 2000 to meet our economic, environmental and social responsibilities and describes how we are striving to create value for the future." John Elkington, Cannibals with Forks: The Triple Bottom Line of 21st Century Business (Stony Creek, CT: New Society Publishers, 1998); The Shell Report: People, Planet and Profits, 2000, p. 1.

4. J. Hill, "Thinking About a More Sustainable Business-An Indicators Approach," Corporate Environmental Strategy, 8/1 (2001): 30-38; L. Preston, "Sustainability at Hewlett-Packard," California Management Review, $43 / 3$ (Spring 2001): 26-37; P.M. Senge and G. Carstedt, "Innovating Our Way to the Next Industrial Revolution," MIT Sloan Management Review, 42/2 (Winter 2001): 24-38.

5. M. Starik and G.P. Rands, "Weaving an Integrated Web: Multilevel and Multisystem Perspectives of Ecologically Sustainable Organizations," Academy of Management Review, 20/4 (October 1995): 908-935.

6. There is considerable debate over the use of the word "sustainability." Part of this debate stems from the fact that activities which are not, in and of themselves, sustainable are often described as "sustainability" activities or initiatives. For example, a corporation with an ecological footprint 10 times its share of the global $\mathrm{CO}_{2}$, cannot, by definition, become sustainable through a $10 \%$ reduction in $\mathrm{CO}_{2}$. However, initiatives designed to reduce $\mathrm{CO}_{2}$ 
output are described as sustainability initiatives. The management at Norm Thompson Outfitters views sustainability, in practical terms, as a process or a journey toward the goal, which is generally the definition given for sustainability. We share this view. Therefore, we identify initiatives that move a firm toward the goal, even if that movement is a reduction in the rate of divergence from the goal, as sustainability initiatives. We recognize that true sustainability requires more, and it is not perfectly clear at this time how to achieve true sustainability.

7. Although Norm Thompson Outfitters approaches sustainability from a triple-bottom-line perspective, this article focuses only on the environmental efforts of the firm. Therefore, we use the term environmental sustainability in this paper to refer to the environmental initiatives implemented by NTO in their pursuit of the triple-bottom-line improvements. See C.A. Ramus, "Encouraging Creative Ideas for Environmental Sustainability," California Management Review, $43 / 3$ (2001): 85-105.

8. J.W. Forrester, Principles of Systems (Cambridge, MA: Wright Allen Press, 1968), p. 1-1.

9. P.M. Senge, A. Kleiner, C. Roberts, R.B. Ross, and B.J. Smith, The Fifth Disciple Fieldbook: Strategies and Tools for Building a Learning Organization (New York, NY: Currency Doubleday, 1994).

10. Ibid.

11. J. Sternman, "Beyond Training Wheels," in Senge et al., op. cit.

12. Forrester, op. cit.; P.M. Senge, The Fifth Discipline: The Art $\theta$ Practice of the Learning Organization (New York, NY: Currency Doubleday, 1990).

13. Young President's Organization connects young global business leaders in more than 75 nations through a peer network for exchanging ideas, pursuing learning and sharing personal and professional growth strategies. More information is available at $<$ www.ypo.org/whoisypo.html>.

14. A study by Environmental Defense indicates that if the catalog industry switched to $10 \%$ post-consumer recycled content, the annual savings would include 851,000 tons of wood, 3.8 trillion BTUs of energy, 521,000 tons of $\mathrm{CO}^{2}$ equivalents, 2.1 billion gallons of wastewater, and 221,000 tons of solid waste. For more information, see "Does your catalog care?" at $<$ www.environmentaldefense.org $>$.

15. Alliance for Environmental Innovation, Greener Catalogs: Improving Paper Practices in the Cata$\log$ Industry, available at <www.environmentaldefense.org/alliance/catalogs.pdf>, 1999.

16. For a complete account of the partnership results see Alliance for Environmental Innovation, A New Norm in Catalogs, available at $<$ www.environmentaldefense.org/documents/2174_ANewNormInCatalogs.pdf>, 2001.

17. NTO is quite interested in encouraging the adaptation and use of this tool and has made it available through the web site of the Businesses for Social Responsibility, at <www.bsr.org $>$.

18. Note that NTO did not actually use systems diagrams to understand their system, nor to analyze how to make changes in its existing system. However, we argue that adopting a systems approach provides a useful tool for understanding and analyzing a system prior to making changes, as well as to do so post-hoc.

19. Margin of the buyers' product portfolio is the contribution margin attributable to the sales of product selected by an individual buyer. This is the excess of the sales revenue generated over the cost of purchasing the product. The buyer's product portfolio identifies the selected products that are placed in the catalog(s) for which the buyer is choosing products. It is computed by multiplying the contribution margin per product times the number of products sold and then summing the contributions across all the different products attributable to the buyer.

20. M. Starik and G.P. Rands, "Weaving an Integrated Web: Multilevel and Multisystem Perspectives of Ecologically Sustainable Organizations," Academy of Management Review, 20/4 (1995): 908-935.

21. Ibid.

22. P. Senge, D. Seville, A. Lovins, and C. Lostpeich, "Systems Thinking Primer for Natural Capitalism: The Four Basic Shifts," draft manuscript, September 2000.

\section{California Management Review}

University of California - F501 Haas School of Business \#1900 - Berkeley, CA 94720-1900 